VLADIMIR PREBILIČ, izr. prof.

Fakultet za društvene nauke Univerziteta u Ljubljani

Kardeljeva pl. 5, Ljubljana, Slovenija

DUNJA DOBAJA, saradnik

UDK 94(497.4)"1915/1917"

Institut za novodobnu istoriju

Kongresni trg 1, Ljubljana, Slovenija

\title{
UTICAJ SOŠKOG FRONTA NA ZALEĐE I SLOVENAČKE CIVILE
}

\begin{abstract}
APSTRAKT: Članak prikazuje italijansku okupaciju austrijske/slovenačke teritorije pored reke Soče, koju je italijanska strana pravdala s uverenjem da „oslobađa neoslobođenu braću“. Italijanska strana je očekivala gostoprimljiv doček kod starosedelaca, ali se to nije dogodilo. Hladan prijem italijanskoj strani rađao je sumnju, koja se postepeno pretvarala u "psihozu straha" odnosno „špijunsku psihozu“. Meštane su optuživali za špijunažu i izdaju italijanskih položaja austrijskoj vojsci. Takva situacija prouzrokovala je nasilne postupke protiv civila. Stvaranje Soškog fronta pokrenulo je i jake migracije naroda. Počeo je period teškog života izbeglica u austrijskim i italijanskim logorima, a ništa bolje nije bilo ni civilima pored reke Soče u periodu od 24. maja 1915. godine do oktobra 1917. godine. Iako je u poređenju sa drugim globalnim ratnim okršajima Prvi svetski rat više puta prikazan kao rat koji nije direktno pogodio civile, ipak su se dešavala i kršenja, doduše retkih, ali važećih pravila međunarodnog vojnog i humanitarnog prava.
\end{abstract}

Ključne reči: Soški front, vojno pravo, civili, logori

Početak Prvog svetskog rata u Evropi ljudi su doživljavali na različite načine. Uprkos tome, čini se da su evropske države bile spremne na rat. Mobilizacija je bila uspešna, odaziv vojnika neočekivano pozitivan, a podrška civilnog življa bila je velika. Vozovi su prevozili oduševljene vojnike na bojišta. ${ }^{1}$ U Sloveniji je mobilizacija počela uvođenjem mobilizacije u Austro-Ugarskoj monarhiji gde nije naišla na takvo oduševljenje kao u drugim delovima Evrope. U sećanjima na detinjstvo Franca Kodriča zabeleženih u

${ }^{1}$ Christian Zentner, Der Erste Weltkrieg - Daten, Fakten, Kommentare, Rastatt, 
građi za kroniku Branik ${ }^{2}$ bilo je zapisano: „Austrougarska je objavila rat Srbiji 28. jula 1914. u noći između subote i nedelje. Naredni dan već su bili po selu obešeni plakati koji su pozivali na oružje sve obveznike do četrdesete godine starosti. Na ponedeljak, 30. jula železnička stanica Rihemberk bila je puna vojnih obveznika koji su odlazili u svoje jedinice. Iz pojedinačnih kuća otišli su baš svi muškarci, čak i po troje i više njih. Muškarci i momci ulivali su ženama, devojkama i roditeljima hrabrost bodreći ih da rat neće dugo trajati. Žene i deca su plakali. Nikome nije bilo do rata. Mnogima ni do Austrije ni do carstva. Neki vojni obveznici su to raspoloženje iskazivali kao poklič protiv monarhije i Austrije. Alojz Ličen, načelnik Sokola, stojeći na stepeniku odlazećeg vagona povikao je: „Živela Srbija, dole Austrija."

Nada da će rat kratko trajati nije se obistinila. Rat je dobio još veću oštrinu kada je italijanska strana neočekivano objavila rat bivšim saveznicama Austriji i Nemačkoj 23. maja 1915, čime je već oslabljen geostrateški položaj Austro-Ugarske monarhije dodatno oslabio. Međudržavna granica koja se rasprostirala od švajcarske granice do Trsta, duga više od $600 \mathrm{~km}$, pretvorila se u ratno bojište. Zbog učestalog nedostatka vojnika u austrougarskoj vojsci, vojni vrh je u početku planirao odbranu tek na reci Savi i Dravi, za šta je bilo predviđeno 20 divizija. Odbrana granice koncentrisala se na zadržavanje prodora italijanskih jedinica. Pošto Italija nije realizovala svoje planove o brzom napadu, bili su revidirani planovi odbrane AustroUgarske, koji su predvideli odbranu iza državne granice u Posočju. Usledila su velika pomeranja jedinica austrougarske vojske, koja je uspela da učvrsti odbrambene položaje pred napadom italijanske vojske. U Posočju, geografsko najmanje zahtevnom delu celokupnog novog fronta - Soškog fronta, sve do kraja 1915. koncentrisale su se obe vojske, italijanska i austrougarska. Tu su se utvrđivali položaji i izvodile mnogobrojne pripreme za dugotrajan rat. ${ }^{3}$ Područje levog i desnog brega Soče, naseljeno većinskim slovenačkim stanovništvom (više od 300.000), postalo je bojno polje. U dvanaest ofanziva borilo se više od milion vojnika, od kojih je život izgubilo oko 200.000. ${ }^{4}$

Kada analiziramo tako obimne ratove, često zaboravljamo na civilni živalj. Istina je da Prvi svetski rat nije bio direktno uperen protiv civila, ali to ne znači da civili nisu stradali ili doživljavali pritiske i druge vrste represalija. Mnogobrojni primeri ponašanja prema civilima obeju strana uticali na su budući razvoj događaja, koji je dostigao negativan zenit u Drugom svetskom ratu. Bez obzira na sve pravne odredbe međunarodnog ženevskog

${ }^{2}$ Cvetko Vidmar, Kronika Rihemberka - Branika, Branik, 1994, 134 (dalje Kronika Rihemberka).

${ }^{3}$ Janusz Piekalkiewicz, Prva svetovna vojna, Ljubljana 1996, 249.

${ }^{4}$ Marko Simić, Po sledeh soške fronte, Ljubljana 1998, 8-9. 
i haškog prava, ponašanje prema civilima u borbama različitog intenziteta nije doživelo očekivanu zaštitu. ${ }^{5}$ Međunarodno vojno pravo je po prvoj međunarodnoj kodifikaciji (ženevske 1867, briselske 1874, haške konvencije 1899. i 1907) doživelo praktično iskustvo upravo u Svetskom ratu. Ovo pravo uvelo je ograničenja kada je u pitanju ratovanje, a prvi put se vojno pravo dotaklo odnosa između civilnog društva i naoružanih sila. Za potrebe razumevanja i zaštite civila u ratovanju, bez obzira na statičnost i doktrinu vojnog okršaja koje nije predviđalo uništenje druge države i njenih državljana, bitno je definisati odnos između okupatora i okupiranih, odnosno između okupatorske vojske i stanovništva i organa okupirane zemlje. Posebno su bitne odluke zapisane u 4 . haškoj konvenciji, gde su jasno određena pre svega prava i obaveze okupatora koje posredno sa svojom tumačenjem štite civilno stanovništvo na okupiranoj teritoriji. Sve to govori o definisanju odnosa između okupatora i stanovništva okupirane teritorije kao o pravnom odnosu gde su vojnoj sili postavljene granice. Sa stanovišta velesila takvo tumačenje bila je neprihvatljiva jer je pomenuto pravo postavilo okupatoru samo ograničenja, a okupiranom stanovništvu priznalo pravo do otpora. Takvi zahtevi bili su postavljeni pre svega od strane manjih država, koje su ih definisale kao obavezu stanovništva prema domovini kao najvećoj dužnosti. ${ }^{6}$

Sa slovenačkog gledišta bila je bitna činjenica da je Italija okupirala teritoriju tadašnje Austro-Ugarske, najviše na desnom bregu reke Soče, čime su njene sile dobile status okupatora. Bez obzira što su odredbe haškog prava postale važeće 26. januara 1910. i za Kraljevinu Italiju, okupacione oblasti koristile su prilično labavo definisane članove haškog prava. U vreme rata bilo je teško govoriti o implementaciji odredaba haškog prava, a još je teže bilo sprovoditi sankcije zbog nepoštovanja i kršenja odredbi, jer međunarodna zajednica tada nije imala instituciju za takva pitanja.

\section{Dolazak italijanske vojske u slovenačke krajeve}

Dana 23. maja 1915. Italija je objavila rat Austriji. Njena vojska je noću prešla granicu. Levi breg Soče bio je glavna linija ratišta. Nastao je 90 kilometara dugačak Soški front, koji je išao duž linije Rombon, Ravelnik, Javorščak, Lipnik, Vršič, Krn, Mrzli vrh, Vodila vrh do Soče. Odavde je front išao po levoj strani reke Soče i spajao se sa dva mostobrana na desnoj

${ }^{5}$ Hague Conferences, The Columbia Electronic Encyclopedia 2000-2006, publishing as Infoplease, 11. mart $2012<\mathrm{http}$ //www.infoplease. com/ce6/history/A0822352.html>.

${ }^{6}$ Marco Sassoli, Antoine A. Bouvier, How Does Law Protect in War-Cases, Documents, and Teaching Materials on Contemporary Practise, International Committee of the Red Cross, Geneva, 1999, 92-100. 
strani reke. Tolminski mostobran, koji se rasprostirao od Soče kod Dolja, Crkve Svetog Danijela, Mengora i kote 588, štitio je stanicu kod Mosta na Soči i operativne pravce prema Ljubljanskoj kotlini. Goričanski mostobran rasprostirao se od Sabotina-Oslavja-Podgore-Kalvarije i trebalo je da štiti Goricu i zadrži italijanski prodor po Vipavskoj dolini. Banjska visoravan bila je odbrambena linija između mostobrana. Do mora italijansku vojsku trebalo je da zaustavi Kraška visoravan. Soški front je bio glavno ratište između Italije i Austro-Ugarske. U jedanaest ofanziva Italijani su pokušali da probiju austrijsku odbranu na Soči, prodru u Ljubljansku kotlinu i zauzmu Trst. Za dve i po godine ratovanja na reci Soči, Italiji je uspelo da realizuje deo svog osnovnog cilja. Najdublje, 12 kilometara, probili su se do Kostanjevice na Krasu, a od Plavi do grebena Banjske visoravni 10 kilometara. $^{7}$

Uspostavljanje Soškog fronta treba razumeti kao dugogodišnje nezadovoljstvo mlade Kraljevine Italije oko granice u jadranskom prostoru. Benito Musolini je u svoj dnevnik zapisao kako je 24. maja italijanska vojska prešla „stare $i$ istinito zločinske granice, koje treba izbrisati, jer su opasne i sramotne, i koje smo dugo trpeli." ${ }^{8}$ Po mišljenju italijanske politike, teritorija koju je okupirala italijanska vojska trebalo je da bude „unutar granica Italije“. "Neoslobođene pokrajine" bile su osnovni cilj italijanske politike i razlog posezanja za ratom. Julijska krajina i Tridentina nisu predstavljale tuđe već nacionalne teritorije u rukama neprijatelja. Okupacijom ovih teritorija Italija bi vratila ono što joj je zapravo pripadalo. Vraćanje teritorija značilo bi ispunjenje politike oslobađanja, uspostavljanje slobode i učvršćivanje nacionalne solidarnosti. ${ }^{10}$ Teritorijalna trenja između Austro-Ugarske i Italije odrazila su se i na svakidašnji život, jer među većinskim slovenačkim življem u Tršćanskom zalivu Italijani nisu bili dobrodošli. Sve je to menjala italijanska objava rata i zbog toga su se meštani koji su živeli oko reke Soče plašili dolaska Italijana, „koje niko nije voleo. Kao slovenački vojnici na frontu, posebno Primorci, i meštani su bili ubeđeni, da ako Italijani okupiraju naše krajeve, ništa se dobro neće dogoditi. Niko tada još nije znao za Londonski dogovor, koji je Italijanima omogućio posedovanje naših teritorija kao dozvolu za ulazak u rat na strani Antante."11

Mada se italijanska strana trudila da predstavi slovenačku teritoriju kao deo italijanske države, strani posmatrači mogli su zaključiti da je pravo stanje drukčije. Spomenimo zapažanja vojnog dopisnika londonskog Tajmsa

\footnotetext{
${ }^{7}$ Petra Svoljšak, Slovenski begunci v Italiji med prvo svetovno vojno, Ljubljana 1991, 7 (dalje: Svoljšak, Slovenski begunci v Italiji).

8 Petra Svoljšak, Soča, sveta reka: italijanska zasedba slovenskega ozemlja (19151917), Ljubljana 2003, 99 (dalje: Svoljšak, Soča, sveta reka).

${ }^{9}$ Isto.

${ }^{10}$ Svoljšak, Slovenski begunci v Italiji, 8.

${ }^{11}$ Isto, 136.
} 
Džona Keridža, koji je bio na goriškom frontu i u Journal de Geneve pisao i o Slovencima koji su tamo živeli, nazivajući ih Jugosloveni. ${ }^{12}$ Džon Keridž je pre dolaska u Brda radio kao vojni dopisnik u Srbiji. Kada je stigao u Brda, koje je nazvao po italijanski Koljo, bio je iznenađen što su domaćini govorili „jugoslovenskim dialektom“13.

Prvi svetski rat je od 1914. do 1918. prouzrokovao migracije i milione begunaca. Počeo je period kada se uspostavilo saznanje da nijedna ratna odluka na bojnom polju neće biti završena sve dok društvo bude moglo da izdrži i proizvodi. Civilno društvo je zbog toga jako trpelo.

Granice između ratišta i zaleđa su se brisale, jer je mobilizacija dotakla sve sfere privatnog i javnog života i sve slojeve stanovništva. Treba reći da je direktno uključivanje civilnog stanovništva u vojne operacije $u$ poređenju sa Drugim svetskim ratom bilo mnogo manje. ${ }^{14}$

Dana 24. maja 1915. italijanska vojska izvela je prvu ofanzivu po planu generala Luidžija Kadorne, načelnika glavnog štaba italijanske vojske. U prvom naletu glavni zadatak imale su 2. i 3. armija. Druga armija je bez otpora zauzela Kobarid. Usledila je okupacija Ježa, Kolovrata i Korada. Preko Brda je napredovala samo 10 kilometara prema Soči i zauzela Števerjan. Treća armija je prvog dana zauzela Červinjan, Krmin i Medeju. Dana 25. maja italijanske jedinice dostigle su Soču između Pierisa i Gradišča i severno od Gorice između Sabotina i Sela. Na Tolminskom su se približile tamošnjem mostobranu, ali nisu iskoristile mali broj branilaca grebena Krn-Sleme-Mrzli vrh, koji nisu osvojili. U narednim danima italijanska vojska oprezno se približavala Sabotinu, Banjskoj visoravni i zapadnom uglu Kraške visoravni. Prvih dana je došlo do većih borbi na teritoriji između Krna i Soče, koje su se za Italijane neuspešno završili. Početkom juna Italijani su zauzeli Gradišče na Soči i Tržič i neuspešno napadali goriški mostobran. Do 22. juna su pokušali da osvoje prelaz preko Soče kod Plava, a na goriškom mostobranu prekinuli su sa daljim pokušajima. ${ }^{15}$ Italijani su,

${ }^{12}$ Slovenec, 8. maj 1917, br. 105, 1-2, Anglež o Slovenskih Brdih.

${ }^{13}$ „Počeo ih je ispitivati odakle su došli odnosno odakle su pribegli. Bio je iznenađen kada je saznao da su to autohtoni meštani koji žive na slovenačkoj zemlji. Do tada je mislio da je to pomenuto područje u celosti italijansko jer su italijanske novine uvek pisale o "neoslobođenoj braći koja jedva čekaju da ih u svoje naručje primi brižna mati." Po pisanju Keridža Jugosloveni iz Gorice su ratne uslove trpeljivo podnosili, ali su izrazili želju za ujedinjenje i suprotstavljanje podeljenosti na više zemalja. Keridža je iznenadio ponos ljudi iz Brica, da su Jugosloveni. Bez obzira na veći broj italijanskih vojnika svuda se mogao čuti domaći jezik. Pohvalio je i njihovu marljivost, inteligenciju i sposobnost za trgovinu. - Slovenec, 8. maj 1917, br. 105, 1-2, Anglež o Slovenskih Brdih.

${ }_{14}$ Petra Svoljšak, Vojna - vzrok in spodbujevalka migracij: primer 1. svetovne vojne in slovenskega prostora, Migracije in slovenski prostor od antike do danes, Ljubljana 2010, 229 231 (dalje: Svoljšak, Vojna - vzrok in spodbujevalka migracij).

${ }^{15}$ Isto, 7-8. 
zbog preterane opreznosti, ${ }^{16}$ uspeli u prvom mesecu rata da načnu austrijsku odbrambenu liniju samo na području Krna i kod Plava, bez obzira na skromnu austrijsku odbranu. Slovenci u Gorici bili su sigurni da će Italijani već prvi dan zauzeti Goricu. Znali su da austrijska granica nije dobro zaštićena. Austrijska vojska je zimi utvrđivala odbrambenu liniju uz Nanos, jer "Austrijanci su hteli da se mere sa Italijanima tek na nanoskim utvrđenjima."

Mnogi italijanski autori o događajima oko Soče navode da su komandanti njihovih jedinica slabo poznavali prave razmere, moć i stanje austrijskih jedinica na tom ograničenom području. Precenjivali su njihov broj i spremnost na rat. Italijanski obaveštajni podaci bili su loši. Samo nedelju dana pred početak rata, italijanski komandanti nisu znali da su austrijski položaji loše obezbeđeni i da na planinskom grebenu Krn-Maselnik-Sleme- Mrzli vrh gotovo nije bilo odbrambenih jedinica. ${ }^{18}$

$\mathrm{Na}$ slovenačku teritoriju, italijanska vojska došla je ubeđena da „spašava nespašenu braću" i samim tim očekivala je dobar prijem. Tako su inače italijanskim vojnicima govorili njihovi komandujući. Stvarnost je bila potpuno drukčija, jer je slovenačko stanovništvo bilo uzdržano i zabrinuto zbog svoje sudbine. Italijanski vojnik Mario Marijani opisao je raspoloženje slovenačkog stanovništva rečima: „Na teritoriji se nismo susreli sa stanovništvom raširenih ruku, a ni sa mržnjom. Ostali su tihi, nekako mračni i odsutni." 19

I sa Furlancima, pravim Italijanima, imali su velike probleme $\mathrm{u}$ komunikaciji zbog njihovog suzdržanog odnosa. O suzdržanosti Furlanaca list Slovenec kaže: „svaka čast furlanskom stanovništvu.“ ${ }^{20}$ Podsticanje proti-

${ }^{16}$ Feldmaršal Svetozar Borojević kasnije je ovako pisao o italijanskom načinu ratovanja u prvim danima: „Prošlo je neverovatno puno vremena da se je Kadorna odlučio za odlučniju akciju." U: Miro Simčič, 888 dni na saoški fronti: spopadi na Krasu in v visokogorju, Ljubljana 2006, 43 (dalje: Simčič, 888 dni). Umesto ofanzivnog prodora počelo je sporo italijansko napredovanje. Mesto glavnog napada, kao što se očekivalo, nisu odmah izabrali već su izveli više manjih napada na mnoge tačke od mora do Rombona. U: Simčič, 888 dni, 43.

${ }^{17}$ Andrej Gabršček, Goriški Slovenci: narodne, kulturne, politične in gospodarske črtice 1901-1924 II, Ljubljana, 1934, 502-503 (dalje: Gabršček, Goriški Slovenci). Andrej Gabršček (1864 Kobarid - 1938), slovenački publicist, izdavač, političar i novinar. Okolnosti na Goriškem kada je izbila mržnja između Italije i Austro-Ugarske opisao je sledećim rečima: „Ja sam bio u redovnim kontaktima sa žandarmerijom (austrijskom - D. D.), jer sam imao za njene zvanične upotrebe sve pretpisane štampane izveštaje. Dolazili su mi i žandari od stare laške granice i krišoma mi govorili da imaju takvu direktivu: Koliko je žandara, pogranične finansijske straže i ono malo crnovojnika (svi od koruške granice do mora bilo je oko 15.000), neka pokušaju Italijane zadržavati toliko vremena, da odu iz Gorice svi evakuisani vozovi, a onda da se povuku uz nanosku liniju."

${ }^{18}$ Vasja Klavora, Koraki skozi meglo: soška fronta, Kobarid, Tolmin 1915-1917, Celovec-Ljubljana-Dunaj, 1994, 48 (dalje: Klavora, Koraki skozi meglo).

${ }^{19}$ Svoljšak, Vojna - vzrok in spodbujevalka migracij, 233.

${ }^{20}$ Slovenec, 10. jun 1915, br. 154, 1, Divjanje Italijanov v našem Primorju. 
vaustrijskog, odnosno italijanskog raspoloženja, u tajnom izveštaju ${ }^{21}$ kancelarije za informisanje kod Vrhovne komande italijanske vojske, pripisivali su pre svega klerikalnoj stranci, koja je koristila mržnju među različitim slojevima stanovništva. Pomenuti izveštaj je sveštenstvo okarakterisalo kao „austrofile“, jer su navodno nagovarali seljake protiv njihovih gospodara, koji su u većini bili italijanske narodnosti, a samim tim nagovarali ih protiv Italije. Već u početku pojave mržnje pokazalo se, po rečima poslanika Luidžija Federkonija, koji je komandovao 4. armadom, da je istočna Furlanija, gde je ostvareno prvo napredovanje italijanskih jedinica, bila "najviše proaustrijska, možda jedina proaustrijska teritorija oslobođenih pokrajina" ${ }^{22}$

Pomenuti italijanski poslanik poslao je pismo predsedniku vlade Italije kako bi mu predočio da italijanski državljani o tome treba da ostanu neinformisani. Prvih dana okupacije, briga o javnom mnjenju u Italiji bila je prioritet italijanske politike. Bilo je bitno sakriti od javnosti negativan i sumnjičav odnos stanovništva okupirane teritorije prema italijanskoj vojsci i prikazati da je italijanska vojska bila „prinuđena“ da oštro reaguje i strelja „pobunjenike“. Italijanskog okupatora je na upotrebu različitih postupaka pre svega protiv slovenačkog sveštenstva, zbog njegovog nepoverenja i nepoverenja stanovništva - navodila „špijunska psihoza“. Bili su uvereni da sveštenstvo špijunira i otkriva italijanske položaje austrijskoj vojsci. Sumnjivo je postalo sve: „kačenje veša, paljenje vatre ili zvonjenje zvona“. ${ }^{23}$ Sumnja „italijanskih oslobodilaca" protiv svih i svakog imala je za posledicu nasilje nad civilnim stanovništvom. ${ }^{24}$

\section{„Kako divljaju Italijani u „oslobođenim“ krajevima“25}

Prvi kontakti vojske sa civilnim stanovništvom odslikavaju pre svega odnos vojnih, odnosno okupacionih jedinica prema civilnom stanovništvu. Vreme ofanziva na svim evropskim ratištima prouzrokovali su isti faktori, pre svega nasilje nad civilima, dobrovoljna iseljenja, nasilna proterivanja

${ }^{21}$ Svoljšak, Soča, sveta reka, 118.

22 Isto. - Ako su bili prvi izveštaji o prijemu italijanskih vojnika u „oslobođenim“ pokrajinama bili uzdržani i pokazivali razočarenje, dela koja su izdata u Italiji u vreme fašizma prikazivala su drugačiju sliku. Govore o oduševljenom prijemu italijanske vojske i o svesnosti Furlanaca, „da su predstraža protiv neprijatelja, bili su ponosni i osećali su bitnost zadatka koji im je bio poveren i pozdravljali su jedinice koje su išle u boj kroz gradove okićene zastavama...". Kao što smo rekli pomenuta dela izdata su u vreme uspona fašizma koje je takođe svoje inspiracije pronalazilo u pobedama u velikom ratu. U: Svoljšak, Soča, sveta reka, 122

${ }^{23}$ Simčič, 888 dni, 43.

24 „Italijani naime nikada nisu bili tako okrutni prema lokalnom stanovništvu kao austrougarski vojnici u Srbiji, gde su 1914. obesili na stotine civila pod optužbom da su špijuni“. U: Simčič, 888 dni, 46, sažeto po Sondhaus L., 2003, XVI.

${ }^{25}$ Citat je uzet iz naslova u listu Slovenec, 7. oktobar 1915, br. 229, 4. 
civilnog stanovništva i zatim vojna okupacija, koja je iskazivala vojnopolitičke planove okupatorske zemlje nad okupiranom teritorijom. U početnoj fazi išlo se, pre svega, na nasilno ponašanje vojske nad civilima i traženje razloga za pomenuto nasilje. ${ }^{26}$

Uzimajući u obzir podatke pomenute u fusnoti, slovenačko iskustvo u pogledu žrtava i intenziteta nasilja bilo je skromnije. Ali, bez obzira na sve, ne možemo ga zanemariti, jer je italijansko nasilje nad civilima u „oslobođenim zemljama" predvidelo kasnije (u periodu između oba svetska rata na Primorju i kasnije u vreme Drugog svetskog rata), još nasilnije postupanje nad svima koji se nisu želeli prikloniti italijanskom gospodstvu. Uzroke nasilja okupatorskih vojski moguće je tražiti u početnom strahu i euforiji kada je izbio rat, $u$ anksioznosti, koju je prouzrokovala masovna mobilizacija, u zabuni i umoru po prvim dugim ratnim vojnim pohodima, a prvenstveno su razlozi bili ukorenjeni u stereotipima o neprijatelju. Obe strane su različite stereotipe utvrđivale i za vreme ratnih priprema i vojnih pohoda. Veliku propagandnu ulogu u tom pravcu imala je štampa. I nemačka i italijanska strana bile su uverene u svoju kulturnu superiornost i tradiciju, što se ogledalo i u odnosu prema civilnom stanovništvu okupirane teritorije. Ako je italijanska vojska došla na austrijsku teritoriju sa naivnim ubeđenjem da "oslobađa neoslobođenu braću“, tako je austrougarska vojska došla na srpsku zemlju ubeđena da su stanovnici "lenji, lopovi i ubice krunisanih glava“ ${ }^{27}$

General Kadorna je u izveštaju o postupcima italijanske vojske sa stanovništvom na okupiranom području napisao da je potrebno uzvratiti primerenom strogošću i da nikakve nepravilnosti koje bi se desile ne smeju ostati nekažnjene. ${ }^{28}$ Uz tako strogo komandovanje, civilno stanovništvo nije moglo ostati nekažnjeno, jer se italijanska okupaciona vlast još u prvim danima pokazala kao dosledan i krut izvršilac generalovih naređenja. Italijanska vojska došla je na okupiranu teritoriju puna sumnji i puno komandanata bilo je opsednuto „psihozom špijuniranja“"29. Bez dozvole vojnih vla-

${ }^{26}$ Rečeno potvrđuju događaji posle prodiranja nemačke vojske u Belgiju, Francusku i Poljsku, u ruskim ofanzivama u istočnu Prusku, Galiciju, Poljsku i Karpate, zajedničkim prodorom austrougarske, bugarske i nemačke u Srbiju i italijanskom prodiranju na Soškom frontu. Godine 1914. ruska vojska je u istočnoj Pruskoj prouzrokovala smrt 6.000 civila i uništenje 42.000 kuća, ${ }^{26}$ u Belgiji i Francuskoj je između 5. avgusta 1914. i 21. oktobra iste godine nemačka vojska zapalila 15.000 kuća, a čak 6.000 civila izgubilo je život u masovnim ubistvima. U: Svoljšak, Vojna - vzrok in spodbujevalka migracij, 231.

${ }^{27}$ Isto, 232-233.

${ }^{28}$ Klavora, Koraki skozi meglo, 76.

${ }^{29}$ Tako su po ispovesti nekog seljaka iz Kozane koji je pobegao u Ljubljanu, meštanima u selu Kozana zapretili da će ih proterati u Italiju, pošto su navodno bili špijuni. Pod optužbom špijuniranja odveli su i kozanskog sveštenika, a poštara u Kozani su zbog „špijunaže" osudili na šest meseci zatvora. U: Slovenec, 7. oktobar 1915, br. 229, 4, Kako divjajo Lahi v „odrešenih“ krajih. 
sti nije smeo niko da napusti svoje ognjište. Čak i za rad na njivi bila je potrebna dozvola. Ljudima su oduzimali kotlove, odeću, hranu, živinu i otkupljivali po polovičnoj ceni ili još niže od prave cene. Italijanske jedinice nisu samo krale već su uništavale njive, kidale nezrelo grožđe, sekle drveće. Vojnike koji su krali, po ispovesti jednog domaćina iz Kozana pomenutoj u fusnoti, navodno su odvodili oficiri. ${ }^{30} \mathrm{U}$ dnevniku jednog palog italijanskog vojnika možemo pročitati da je "dolazilo i do sudskih postupaka protiv takvih prestupnika $^{\text {“31 }}$ (krađe imovine domaćina - D. D.), što su bili retki primeri ako imamo u vidu vest koju je preneo Slovenec. ${ }^{32}$

Ofanzivne italijanske vojne jedinice su loše postupale sa domaćim stanovništvom i nisu mu verovale. Po svedočenju očevidaca, pojedine italijanske jedinice su bile korektnije prema stanovništvu na okupiranim područjima. Štefan Gaberščik, nekadašnji krčmar iz sela Smast kod Kobarida, opisao je puk koji je 24. maja 1915. okupirao njegovo selo: „Istini na volju moram pomenuti da su bili ti vojnici koliko toliko dobri prema nama, čak su nam $i$ hleb besplatno delili“. ${ }^{33}$ Većina muškaraca regimenta, koji pominje Gaberščik, stradala je u borbama na Krnu. Zbog toga su u selo Smast kao neki osvetnici došli italijanski Alpini, koji su se ponašali potpuno suprotno od njihovih prethodnika. Bili su „zli i krvoločni, kao da ih je sam đavo doveo iz pakla". ${ }^{34}$

Italijani su domaćine najviše optuživali za špijuniranje, odavanje strateških podataka neprijatelju, uopšte saradnju sa austrougarskom vojskom i streljanja italijanskih vojnika. Italijanski komandanti su se striktno pridržavali instrukcija vojnog vrha o tome da na okupiranom području moraju delovati strogo i kazniti svaku nepravilnost. Okolnosti su se toliko zaoštrile da su se sa domaćinima i fizički obračunavali, čemu su sledila i prva ubistva civila. Najpoznatija ubistva u Gornjem Posočju desila su se 4. juna 1915. kod Idrskog, gde su po sistemu desetkovanja kao taoce streljali 6 ljudi iz sela Smast i Kamno. Domaćine su greškom optužili za napade i streljanja ranjenih italijanskih vojnika. U selima Ladra, Smast, Libušnje, Vrsno, Krn i Kamno su, po nekim izvorima, uhvatili 61 , a po drugim 66 domaćina $^{35}$ i odveli ih preko Soče. Ispred sela Idrsko su ih postrojili i svakog desetog

30 Isto

${ }^{31}$ Klavora, Koraki skozi meglo, 47.

${ }^{3}$ Slovenec, 7. oktobar 1915, 4, Značilna sodba laškega polkovnika o roparskem laškem napadu.

${ }^{33}$ Slovenec, 21. maj 1917, št. 115, 2, Zgodba našega ujetnika na Laškem.

34 Isto

${ }^{35}$ Pomenuti Štefan Gaberščik iz Smasti koji je bio i među optuženima pominje broj 66. U: Slovenec, 21. maj 1917, 2. Novina Istra, 14. jun 1935, br. 24, govori o oko 60 muških, Branko Marušič, Italijanska okupacija Posočja (1915-1917), Zgodovinski časopis, br. 2, Ljubljana 1989, 233 govori o broju 61. 
streljali, a posle ih na istom mestu zakopali. Posle rata, 1920. godine oni su sahranjeni na civilnom groblju u Kobaridu i na groblju kod Crkve Svetoga Lovrenca. ${ }^{36}$

Zločin u Idrskom je primer kada je vojna komanda za neuspehe i greške koje su u redovima italijanske vojske prouzrokovali ne samo austrijski branioci već sami italijanski vojnici i karabinjeri, optužila obične seljake iz podkrnskih sela. Vojna situacija na periferiji Krnskih planina bila je za italijansku stranu neuspešna. ${ }^{37}$ Krajem maja 1915. cilj italijanskih napadača bili su Mrzli vrh i planina Sleme, ali su austrijski branioci odbijali napade. Zbog toga se među italijanskim vojnicima pojavio paničan strah i mnoštvo dezertera, koji su se sakrivali kod seljaka. Seljaci su ćuteći trpeli, jer su se plašili osvete dezertera. Usledio je sudbonosni 4. jun 1915. kada su italijanske jedinice još silovitije napale, ali bez uspeha. Italijanski vojnici su bezglavo bežali u dolinu i pri tom susreli grupu karabinjera, na koju su počeli da pucaju. Navodno su streljali po vojnoj bolnici u Ladri i za to okrivili domaće stanovništvo. Pomenuti zločin nad civilnim stanovništvom nije bio jedini toga dana. Još na putu do mesta streljanja kod Idrskog, Italijani su bez razloga ubili dva seljaka (muža i ženu) iz sela Ladri, dok su radili na njivi. Van sela Smast, bez povoda su ubili jednog seljaka iz grupe 66. Ostale, njih 65 (oslanjajući se na priču preživeloga Štefana Gaberščika) odveli su u Idrsko, gde su kod idrskog mosta na komandu italijanskog oficira postavljeni u red i pretreseni. Potom je 16 italijanskih vojnika svakog desetog ubilo sa četiri pucnja. ${ }^{38}$ Preživele iz grupe 66 su odveli u Kobarid. Štefan Gaberščik kaže da su na putu sreli odeljenje italijanskih Alpina, koji su ih „tukli, gurali i pljuvali. Sa Krna su terali strica Šmonovog, koji je bio slabog uma, i pošto nije hteo da ide, ubili su ga udarajući ga sa palicama kao neku žabu. “39 $\mathrm{U}$ Kobaridu su italijanski vojnici nastavili sa zločinima. ${ }^{40}$

O nekulturi i nelojalnosti italijanskih jedinica govore i druga nasilna događaja na Primorju. Krajem maja 1915. italijanska vojska je u kraju Vileš (Villesse) kod Gradišča kod Soče, nedaleko od slovenačko-romanske jezičke granice, streljala šestoro meštana pod optužbom da su oni streljali italijan-

${ }^{36}$ Tadej Koren, Idrsko, 4. junij 1915: prve civilne žrtve I. svetovne vojne iz vasi ob Soči, Kobarid 2010, 4-5 (dalje: Koren, Idrsko, 4. junij 1915).

${ }^{37}$ Svoljšak, Soča, sveta reka, 151-152.

${ }^{38}$ Slovenec, 21. maj 1917, 2.

${ }^{39}$ Isto

40 Josipa Gregorčiča, Podskednarjevega s Krna, pred kobaritskim sudom prebili su na smrt. Ostale su sutradan odvezli u Čedad gde su u školskoj zgradi ostali skoro dva meseca. Potom su ih transportovali vozom u Firencu, a odatle posle dve nedelje u Oskijeri na Sardiniji. Zbog surovih uslova u izbeglištvu umro je Anton Falič, zvani Belin, iz Smasti. Posle tri nedelje, muškarce do 18 i preko 50 godina odvezli su u Valthofen u Austriju. Na putu su se četvorica razbolela, a trojica iz sela Smast su umrli. U: Slovenec, 21. maj 1917, 2. 
ske vojnike. ${ }^{41} \mathrm{U}$ Tržiču su posle torture streljali sveštenika Krena. U Koprivi kod Gorice oterali su sveštenika dok je služio liturgiju i okovanog ga odveli u ropstvo. Slično su postupali sa sveštenstvom koje je odbijalo da se za vreme liturgije pomoli za pobedu italijanske armade i zdravlje italijanskog kralja. $^{42}$

Streljanje civilnog stanovništva bila je česta mera prema stanovništvu okupiranih teritorija, posebno u početnoj fazi okupacije. Služila je kako za primer tako i za represalije. Najčešća mera vojske za nadzor okupiranih teritorija bila je internacija, odnosno nasilno odvođenje sumnjivih osoba. Takve postupke činila je i vrhovna komanda italijanske vojske, koja je u ime zaštite nacionalnih interesa odredila da se sklone osobe koje su mogle da naškode državi i neprijatelju prosleđuju informacije. Na to je italijansku vojsku navodila i „špijunska psihoza“, odnosno nepoverljiv odnos između vojske i civilnog stanovništva i duboko nepoznavanje kulturne, društvene i ekonomske realnosti područja oko fronta. ${ }^{43}$

Pogrešna i jednostrana bila bi tvrdnja da su svi pripadnici italijanskih jedinica koje su prodirale na slovenačku teritoriju zagovarali nasilne postupke prema civilima. List Slovenec je objavio zanimljivu priču uhvaćenog italijanskog vojnika Tomaza Ličelija, po profesiji trgovca iz videmskog okruga, koji je sa svojom jedinicom došao preko Kormina, Medane i Dobrove u Goricu, gde su ga zarobili. ${ }^{44}$ Taj italijanski zarobljenik je okarakterisao stanovništvo prvog okupiranog sela Medeje kao mirno i korektno. Komandant Ličelijeve jedinice bio je zadovoljan odnosom, što je i javno potvrdio kada je odlazio. Svakako su ta "mirnoća“ i „korektnost" stanovništva bili posledica straha budući da je italijanski komandant pri dolasku u Medeju upozorio gradonačelnika na potrebu da se stanovništvo ponaša mirno, jer bi u slučaju najmanjeg znaka otpora bio prinuđen da primeni stroge mere. ${ }^{45}$

Te činjenice možemo različito da interpretiramo, ali je najverovatniji razlog za takvo ponašanje italijanske vojske moguće pripisati pre svega „psihozi straha“, „špijunskoj psihozi“ i osveti prema mnogobrojnim taktičkim greškama pojedinih komandanta. Zašto su se okupatoru moguće provokacije zbog pomenutih "psihoza“ činile gore nego što su zapravo bile? Možda možemo na to pitanje odgovoriti jednostavnom rečenicom - „Pa bio je rat".

\footnotetext{
${ }^{41}$ Klavora, Koraki skozi meglo, 78.

${ }^{42}$ Slovenec, 10. jul 1915, 1.

${ }^{43}$ Svoljšak, Soča, sveta reka, 156-160.

${ }^{44}$ Slovenec, 11. septembar 1915, br. 207, 2, Kako je v zasedenih krajih?

${ }^{45}$ Isto.
} 


\section{Seobe civilnog stanovništva}

Seobe slovenačkog življa u Prvom svetskom ratu dele se na više perioda i pravaca migracija. Najveću grupu predstavljaju izbeglice iz Gorice, koji su se tokom formiranja Soškog fronta zatekli u unutrašnjosti AustroUgarske. Istovremeno se u 1915. godini dogodilo, ali brojno skromnije, kretanje 10.000-12.000 stanovnika u Italiju. Treći izbeglički talas, kao posledica italijanske okupacije Gorice avgusta $1916,{ }^{46}$ ponovo se okrenuo ka austrijskim pokrajinama. Italijanski slom kod Kobarida 24. oktobra 1917. prouzrokovao je manji izbeglički talas koji je zahvatio pre svega Furlance iz Furlanije i Veneta, jer su slovenačka sela bila iseljena još 1915. godine. Kraj rata prouzrokovao je nove migracije slovenačkog stanovništva. Posle italijanske okupacije slovenačke teritorije, mnogi primorski Slovenci otišli su u Kraljevinu SHS, gde je ostalo oko 15.000 slovenačkih međuratnih izbeglica koje zbog italijanske okupacije nisu više želeli da se vrate u svoje domove. $^{47}$

Početnoj italijanskoj ofanzivi i talasu nasilja sledile su nove mere, isterivanje civila sa matične teritorije. Neki stanovnici su se preventivno sklonili pred samu ofanzivu italijanske vojske. Austro-Ugarska je kod svojih državljana delovala preventivno, jer je prvi i najveći talas izbeglica morao napustiti svoje domove još pred sam početak rata sa Italijom. Na dan 22. maja 1915. austrougarske vojne vlasti izdale su naređenje o evakuaciji krajeva na kraškoj periferiji. Stanovništvo je za samo dva sata moralo uzeti najneophodnije stvari i stići na vozove koji su ih dovezli u unutrašnjost monarhije. Tih dana odselilo se i stanovništvo slovenačkih sela u Brdima i na levoj strani reke Soče. Dana 23. maja morali su se iseliti stanovnici gornje soške doline. Otišli su do Trente, Kranjske Gore ili Podkorena i dalje u izbegličke logore u Dvojnoj monarhiji. ${ }^{48}$ Dana 8. juna 1915. austrougarsko Ministarstvo unutrašnjih poslova poslalo je svim pokrajinskim vladama dopis sa molbom da ljudi lepo prihvate izbeglice, „koje su najveće žrtve svet-

${ }^{46}$ Sudbina Gorice je inače bila između dve vatrene linije koje su određivale i tokove migracije u gradu. Prva migracija dogodila se u vreme sve veće napetosti sa Italijom i kada je počeo rat sa njom. Tada su otišli svi oni kojima je to zbog bezbednosti naredila viša vlast, goričanski pokrajinski odbor i „bojažljivci“. U prvoj grupi „ne bi bilo puno ljudi“. Druga migracija stanovništva desila se kada su „Italijani slali svoje šrapnele i granate na naše glave“. Još juna 1915. grad je napustila polovina stanovništva - 15.000 žitelja, a do kraja novembra u gradu je ostalo 5.000 stanovnika. Posle italijanske okupacije Gorice 9. avgusta 1916. italijansku vojsku dočekalo je 3.200 ljudi, a pred 12. sošku ofanzivu ostalo je samo 2.000 ljudi. Takvo stanje se ocenjuje kao „istorijski minimum gradskog stanovništva“. U: Svoljšak, Vojna vzrok in spodbujevalka migracij, 237-238.

\footnotetext{
${ }^{47}$ Svoljšak, Slovenski begunci v Italiji, 3 (dalje: Svoljšak, Slovenski begunci v Italiji).

${ }^{48}$ Svoljšak, Vojna - vzrok in spodbujevalka migracij, 237.
} 
skog rata ${ }^{49}{ }^{49}$ Bez obzira na molbu, prema izbeglicama se različito postupalo. U Grac, u austrijsku Štajersku, austrijske vlasti slale su samo furlanske izbeglice, navodno jer su „bolji ljudi“ za koje je potrebna veća briga nego za Slovence. Do sredine septembra 1916. tamo ih je bilo oko 4.000. Među njima bili su i pokrajinski poslanik Pičini i kavaljere Blazig iz Ronkova, koji su u opštini formirali „pomoćni odbor za furlanske izbeglice“. Taj odbor se odnosio samo za Furlance, iako su već imali državnu podršku. Za Slovence se taj odbor nije mnogo brinuo. ${ }^{50}$

Slična "protekcija“ furlanskih begunaca postojala je i u drugim delovima Austrije. U Beču je tokom avgusta uspostavljen Pomoćni odbor za izbeglice sa juga. Odboru je predsedavao nekadašnji ministarski predsednik dr Maks Vladimir Bek, a za potpredsednika bili su imenovani goriški pokrajinski guverner dr Luidži Fajduti i načelnik tridentinskog seljačkog odbora Mersi. ${ }^{51}$ Ured je imao Informativnu kancelariju za izbeglice i podružnicu u Lipnici, preko koje je na sever otišlo 100.000 izbeglica i 40.000 izbeglica u Ugarsku. U užem odboru, koji se bavio isključivo izbegličkim pitanjima, slovenačke interese zastupali su dekan Ivan Rojec, koji je godinu dana bio i biskupski komesar za izbeglice iz Gorice i Poreča, i dr Anton Gabrijelčič, član kasacionog suda. Odbor je imao više funkcija, a prvi njegov zadatak bio je popis izbeglica i mesta njihovog naseljenja. Pokrenuo je akciju za skupljanje doprinosa za podršku izbeglicama, a brinuo se i o zapošljavanju nezaposlenih izbeglica. ${ }^{52}$

Na početku rata „protekcija“ furlanskih izbeglica, po pisanju Gabrščeka, nije se primećivala jer je postojalo dovoljno finansijskih sredstava, namirnica i dobre volje za pomoć izbeglicama. Tada je po podacima pomenutog odbora bilo 120.000 izbeglica sa Primorja za koje je brinula vlada: $\mathrm{u}$ Lipnici 22.000, Potendorfu kod Beča 800, Matersdorfu 8.000, Gmendu 20.000, Štajnklamu 1.000, u Bruku 5.000. U svim pomenutim izbegličkim logorima nalazili su se crkva, škole, društva i drugo. ${ }^{53}$

$\mathrm{Za}$ „zapostavljenost" slovenačkih izbeglica bila je kriva neorganizovanost među samim Slovencima i loše zajedničko povezivanje i nastupanje. Postojale su kritike na rad predstavnika slovenačkih izbeglica, ali je njihova angažovanost ipak bila korisna za izbeglice. Nekada su bili uspešni, a nekada nisu. U početku je postojala „neorganizovanost“ među slovenačkim

${ }^{49}$ Gabršček, Goriški Slovenci, 508. Umesto države brigu o vojnim izbeglicama preuzelo je austrougarsko Ministarstvo unutrašnjih poslova koje je delovalo preko pokrajinskih vlada, namesništava, poglavarstva i opština.

${ }^{50}$ Isto, 511.

${ }^{51}$ Isto, 513; Petra Svoljšak, Darja Pirih, Damjana Fortunat Černilogar, Lovro Galić, Tolminsko mostišče II, Tolmin 2005, 11 (dalje: Tolminsko mostišče).

${ }^{52}$ Tolminsko mostišče, 11.

${ }^{53}$ Isto. 
predstavnicima, a potom je u novoj situacija trebalo u kratkom vremenu obezbediti podnošljiv smeštaj za ogromnu masu ljudi.

Kada su italijanske vojne vlasti došle na slovenačku teritoriju, odredile su evakuaciju iz bezbednosnih razloga. To znači da se moralo iseliti stanovništvo iz mesta koja su bila 500 metara udaljena od operativnog područja. Iseljavani su stanovnici obližnjih sela u zaleđu, a potom raseljeni po Italiji. Bezbednosnim razlozima iseljenja stanovništva na području Kobarida u Gornjem Posočju pridružili su se i politički odnosno represivni razlozi, kada je zbog umišljenog ili stvarnog delovanja pojedinaca kolektivna kazna iseljenja snašla celokupnu zajednicu. Većina slovenačkih izbeglica iseljenih u Italiju napustila je svoje domove prvih nedelja vojne okupacije. ${ }^{54} \mathrm{O}$ političkim razlozima evakuacije zvanični izvori ne govore ništa. ${ }^{55}$

Pored evakuacijom, italijanska okupaciona politika služila se i internacijom kao posledicom „špijunske psihoze“, koja je proganjala italijansku vojsku posle dolaska u austrijsku zemlju. Zbog toga je do hapšenja i internacija sveštenstva i civila došlo već 24 . maja 1915, što se događalo i u narednim nedeljama. ${ }^{56}$ Uhapšen je 41 furlanski sveštenik i 18 slovenačkih sveštenika ${ }^{57}$ iz Brda i Posočja, kao i monah Ludvik Zorzut. Među civilima su hapšeni pre svega predstavnici lokalnih vlasti i učitelji. Zanimljivo je da pomenuta hapšenja nisu zahvatila samo Furlaniju, Brda i Posočje, nego i druge italijanske pokrajine. Na leto 1915. internirano je čak 70.000 osoba. ${ }^{58}$ Internacijama sumnjivih osoba, i u samoj Italiji, doprinelo je i shvatanje uloge države. U tome su se slagali i predsednik italijanske vlade Antonio Salandra i komandant italijanske vojske Luidži Kadorna, koji su inače politički, kulturno i lično bili jako različiti. Dobrobit države bila je iznad dobrobiti njenih državljana, a ko se sa tim nije slagao bio je interniran. To što je činio Kadorna na vojnom području, Salandra je sprovodio u unutrašnjosti države. ${ }^{59}$ Sumnjičav odnos italijanske vojske prema stanovništvu na austrijskom području prouzrokovao je hladan odnos stanovništva prema prodiru-

${ }^{54}$ Svoljšak, Vojna - vzrok in spodbujevalka migracij, 237.

${ }^{55}$ Svoljšak, Slovenski begunci v Italiji med prvo svetovno vojno, 11.

${ }^{56}$ Luidži Fajduti (1861-1931), pokrajinski poglavar, vođa katoličke narodne stranke, koja je imala jakog saveznika među furlanskim seljačkim stanovništvom vernom monarhiji i caru. U: Svoljšak, Slovenski begunci v Italiji, 11.

${ }^{57}$ Slovenačke sveštenike su Italijani na mnogim mestima zamenili italijanskim sveštenicima. U Vipolžama su postavili sveštenika iz Italije koji je pobegao kada se povlačila italijanska vojska, ali su ga austrijske čete uhvatile, dovele u Goricu i potom u Vipolže. Nije razumeo ni reč slovenačkog. U: Slovenec, 15. novembar 1917, br. 262, 4, Primorske novice.

\footnotetext{
${ }^{58}$ Isto

${ }^{59}$ Svoljšak, Soča, sveta reka, 158-160.
} 
ćoj italijanskoj vojsci i predrasude prema Furlancima i Slovencima. U periodu pred rat veći broj Furlanaca se zbog ekonomskih razloga iselio u Austriju i Nemačku, gde su i po povratku u svoje domove zadržali svoju imovinu. Prema Slovencima su gajili predrasude zbog njihovog jezika koji nisu razumeli i drugačije kulture. ${ }^{60}$

Za sve izbeglice sa područja oko Soče, izbeglice iz Goriških Brda, sa prostora između Soče i Idrije i izbeglice iz kobaridske i bovske kotline, takvo iskustvo je bilo traumatično. Svako je tu traumu pokušavao da preživi sa što manje posledica po sebe, porodicu i imovinu. Italijanska vlada (brigu o izbeglicama je preuzelo Ministarstvo unutrašnjih poslova) nije zanemarivala brigu o izbeglicama kada su stigli na cilj. Smestila ih je u stanove, dobili su novčanu pomoć koja je uglavnom iznosila jednu liru po osobi na dan, mada su izbeglice nalazile i dodatne izvore prihoda. Mada hrana nije bila jeftina, bilo je dovoljno i moglo se preživeti. Namirnice su kupovali preko knjižice u državnim skladištima. Za porodičnu zaradu su u velikoj meri bile zaslužne devojke, koje su u raznim ustanovama i manastirima pomagale u kuhinji i dobijale po 3 lire nedeljno. U industrijski razvijenom Pijemontu, izbeglice su tražile posao u fabrikama i kod zanatlija, a na selu kod seljaka. ${ }^{61}$ Slovenačke izbeglice $u$ Italiji su najviše novca trošile za hranu. Kad je reč o snabdevanju imali su više sreće nego izbeglice u češkim, austrijskim i moravskim logorima, koji su izbeglištvo preživeli više gladni nego siti. ${ }^{62}$

Razlog boljeg položaja slovenačkih izbeglica u Italiji bila je činjenica da ta država nije imala probleme sa snabdevanjem i nije pretpela ekonomsku krizu kao Austro-Ugarska i Nemačka. Položaj izbeglica u Austro-Ugarskoj slabio je zbog sve veće ekonomske krize, deficita osnovnih namirnica i sve veće gladi. Takve ekonomske prilike uticale su na pogoršanje odnosa meštana prema izbeglicama, iako je u početku domaće stanovništvo sa sažaljenjem gledalo na izbeglice. Vremenom su im postali teret, jer su za njih postali samo beskorisna, gladna usta.

${ }^{60}$ Svoljšak, Slovenski begunci v Italiji, 11.

${ }^{61}$ Isto, 25 .

${ }^{62}$ Isto, 31. Za ilustraciju beležimo ispovest Ide Pavlice iz Rihemberka - Branika koja je morala da ode u izbeglištvo kada je imala samo 7 godina. Zajedno sa majkom i četiri sestre snašla se u izbegličkom kampu Štajnklam, dok je otac bio na ratištu kod Kranjske Gore. U svom svedočenju kaže: „Mama se zaposlila. Dobila je težak posao, prevozila je šljunak u kolicima. Starija sestra vezla je čipke, a ostale smo pohađale školu. Predavale su nam slovenačke učiteljice...Hrana koju smo dobijali u logoru bila je loša, zato smo bile srećnije kada nam je mama donela krompir koji je zaradila prevozeći šljunak. Ljuske od krompira smo osušile na vatri i sačuvale. Kada je ponestalo krompira jele smo i ljuske. Hranu u logoru finansirala je neka grofica. Kada je došla u barake probala je hranu. Stavila je kašiku u usta, ispljunula i rekla: Gut, gut!". U: Kronika Rihemberka, 137-138. 


\section{Život na okupiranim područjima}

Uporedo sa okupacijom mesta na Bovskom, Kobaridskom, u Goriškim Brdima i u istočnoj Furlaniji, pa i u južnom Tirolu (Tridentu) italijanske vojne vlasti morale su se pobrinuti i za organizovanje civilne uprave. Krajem maja 1915. formiran je Generalni sekretarijat za civilne poslove koji je vodio generalni sekretar, general Agostino Dadamo. ${ }^{63}$ Uzimajući u obzir međunarodne ugovore, Italijani su morali na okupiranim područjima zadržati austrijsku administrativnu podelu. Generalni sekretar je za svaki politički okrug imenovao civilnog komesara, koji je imao iste nadležnosti kao predratni austrijski okružni glavari. Tako je na Bovskom, Kobaridskom i delu Tolminskog bio obrazovan civilni komesarijat za politički okrug Tolmin, koji je imao sedište u Kobaridu (između aprila i jula 1916. sedište je prebačeno u Breginj). Italijani su u okupiranim mestima raspustili opštinske uprave, ali su one nastavile rad dok generalni sekretar nije imenovao u pojedinim opštinama novog privremenog gradonačelnika. Ponegde su italijanske vlasti za nove gradonačelnike imenovale predstavnike prethodne vlasti, ali to nije bilo pravilo. U Kobaridu je na primer italijanski oficir vodio opštinsku upravu, ${ }^{64}$ dok funkcioneri i gradonačelnici nisu imali nikakav odlučujući uticaj. Administrativni jezik u opštini bio je italijanski i celokupna dokumentacija, čak i molbe građana, pisani su na ovom jeziku. Radne obaveze Generalnog sekretarijata za civilne poslove bile su i školstvo, zdravstvo, pošta, ekonomija, saobraćaj, podrška stanovništvu, čiji su rođaci bili pozvani odnosno mobilisani u austrougarsku vojsku itd. Zamenik generalnog sekretara Karl Galija je oktobra 1915. uputio dopis civilnom komesaru za tolminski okrug u Kobaridu u vezi sa snabdevanjem porodica čiji su se rođaci našli u austrougarskoj vojsci. Septembra 1915. u opštinama Kobarid, Kred, Libušnje, Tolmin i Livek za pomenute porodice namenjeno je 19.332 lire i 37 centezima, navodi se u dopisu. ${ }^{65}$

Nova italijanska vlast uvela je i novu valutu - liru. Stanovništvo je hranu kupljenu u vojnim skladištima moglo plaćati krunama, ali po novom kursu. Italijanska banka (Banco D' Italia) odredila je 24. juna 1915. kurs lire i krune, koji je iznosio 87 lira za 100 kruna. Prilikom promene kruna menjačnice su zaračunavale dodatnih $10 \%$, tako da je stanovništvo u toj transakciji gubilo više od petine vrednosti krune. Budući da na području Kobarida u toku rata nije delovala nijedna štedionica, italijanske vlasti su krajem aprila 1916. otvorile u Kobaridu poštansku štedionicu. Kamata je

${ }^{63}$ Drago Sedmak, Življenje v Kobaridu med prvo svetovno vojno, Celovec 2001, 73 (dalje: Sedmak, Življenje $v$ Kobaridu).

${ }^{64}$ Slovenec, 15. novembar 1917, br. 262, 5, Črtice o Kobaridu.

${ }^{65}$ Sedmak, Življenje v Kobaridu, 76. 
iznosila 2 lire 88 centezima za 100 lira. ${ }^{66}$ Štedionica je uspešno delovala, sudeći prema izveštaju međuratnog italijanskog gradonačelnika u Kobaridu, poručnika Umberta Petranjanija. Posle povlačenja italijanske vojske oktobra 1917, suma ušteđenog novca u kobaridskoj štedionici iznosila je 47.500 lira. $^{67}$

Do kraja juna 1915. u Kobaridu nije delovao poštanski ured. Na posredovanje generalnog sekretara za civilne poslove italijansko Ministarstvo pošta izdalo je početkom jula 1915. uputstva za formiranje poštanskih ureda u opštinama Trnovo kod Soče, Breginj i Kobarid. Italijanska vojna uprava je dobro snabdevala kobaridsko stanovništvo, sudeći prema pisanju lista Slovenec. ${ }^{68}$ Namirnice, osim šećera, bile su jeftine. Pri kupovini drva, koja su bila deficitarna, trebalo je izmeriti njihovu težinu i na osnovu toga odrediti cenu. Slovenec je novembra 1915. doneo vest da će iz Brda stići manje voća jer Italijani, zbog deficita drva za ogrev, seku stabla voća ${ }^{69} \mathrm{Si}-$ romašni su besplatno dobijali namirnice, najviše pirinač, testenine, a manje brašna, pogotovu pred kraj italijanske okupacije. Za zapršku im je umesto svinjske masti služilo ulje od suncokreta. Svinje zbog bolesti u celom okrugu nisu smeli gajiti. ${ }^{70}$

Italijanska strana je podsticala izradu rukotvorina i zanatstvo među meštanima. Tako je kobaridski dekan Jurij Peternel početkom januara 1916. obavestio stanovništvo Kobarida da će italijanska vlada podržati zanate među tamošnjim stanovništvom na taj način što bi se ljudima podelila vuna od koje bi ispleli rukavice, čarape, džempere i drugo. Te rukotvorine bi Italijani otkupili od njih po primerenoj ceni. Peternel je podržao tu ideju, jer je smatrao da posao donosi ljudima zaradu, a lenjost je za njega bila uzrok duhovne i materijalne propasti. ${ }^{71}$ Teži uslovi su bili za stanovništvo koje se izdržavalo samo od poljoprivrede, jer im je još austrougarska vlast oduzela većinu radne stoke i nisu mogli obrađivati njive kao pred rat. Kada je sredinom aprila 1916. u Kobarid došao general Akile Papa za komandanta grada, i sam je video puno kvalitetnih ali neobrađenih njiva. Ljudima je nedostajalo stoke i radne snage, uzevši u obzir da su muškarci uglavnom pozvani u austrougarsku vojsku. Na njegovu inicijativu uređene su bašte $u$ kojima su počeli proizvoditi povrće i saditi voće, a naređeno je da se na njivama seje veća količina krompira i žita. Kao radnu snagu angažovao je italijanske vojnike koji su većinom bili seljačkog porekla. Generalove napore da se intenzivira obrada zemlje podržao je i Peternel, koji je inače otvoreno

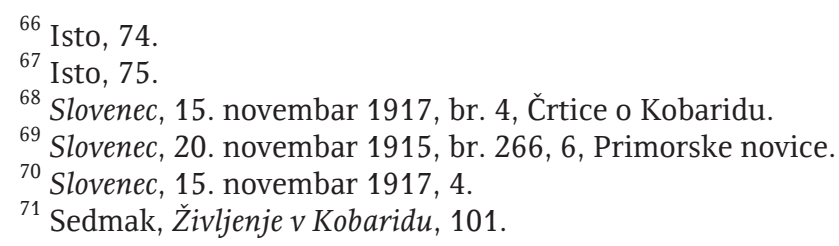


nastupao protiv okupatora kao odlučan Slovenac. Kobariđanima je savetovao da što pre obrade njive i tako ispune svoju dužnost. ${ }^{72}$

Italijanske okupacione vlasti su očigledno vodile računa o poljoprivredi i podsticale njen razvoj, o čemu govori i izveštaj posle odlaska Italijana zabeležen u listu Slovenec. ${ }^{73} \mathrm{Na}$ osnovu datih instrukcija još prvih dana okupacije, kada su gradovi u većini slučajeva bili zapušteni jer je stanovništvo pobeglo na austrijsku stranu, skupile su rasejanu stoku, pokupile zrele prinose i obavile berbu. Potom su sve to, kao i zalihe žita nađene po podrumima i ostavama, prodali a novac, po odbijenim troškovima, uložili u opštinske blagajne gde se čuvao za njihove vlasnike ${ }^{74}$. Vodili su računa i o obrađivanju drugih imanja. U početku su italijanske okupacione vlasti imale problema sa snabdevanjem poljoprivrednim potrepštinama i radnicima. Kasnije, 1916. i 1917, uspelo im je da za okupirane teritorije pribave veštačko đubrivo, seme, plavi kamen, sumpor, oruđe i obrade područja koja su 1915. godine ostala neobrađena ili je na njima izrastao sirak. ${ }^{75}$

Italijanska okupaciona vlast težila je da obradi sve plodne površine u praznim opštinama. Vrhovna komanda je izdala naređenje o obaveznom obrađivanju neobrađenih površina, pogotovu ako je procenjeno da je obrađivanje neke površine za dobro privrede i opšte javno dobro. Briga za obrađivanje bila je poverena vlasniku, staratelju, opštinskoj upravi, seljačkim zadrugama ili vojnoj upravi. Prinose su trebali da podele onima koji su imali pravo na zemlju. O tehničkoj i finansijskoj podeli useva brinuo je Generalni sekretarijat. Mera o obaveznom obrađivanju njiva imala je višestruku namenu: podsticanje domaćeg stanovništva u obrađivanja njiva, smanjenje štete nastale zbog neobrađivanja zemljišta $u$ dužem periodu, poboljšanje higijenskih uslova zemljišta, proizvodnja useva u blizini operativne zone za potrebe vojske, zaštita terena i indirektna pomoć izbeglicama kroz smanjenje troškova za ponovno osposobljavanje zemljišta posle njihovog povratka. ${ }^{76}$

Stanovništvo okupiranog slovenačkog područja, i bez tih mera italijanskih okupacionih vlasti, bilo je svesno potrebe hitnog rešavanja problema u poljoprivredi, jer su ih na to terale okolnosti. U početku italijanske okupacije rad na njivi bio je otežan. Razlog su bile i same okupacione vlasti, koje su stanovništvu zabranile rad na njivama zbog sumnje da su špijuni.

${ }^{72}$ Isto, 103.

${ }^{73}$ Slovenec, 4. jul 1917, br. 150, 5, Primorske novice.

${ }^{74}$ Tako su u Moši našli za 14.367 lira stoke, u Fari za 2.996,32 lira sena i za 61.704 lira ostalog. U Furlaniji su na čelo velikih farmi postavili plaćene upravnike, a prihod sa tih farmi su ulagali u italijansku državnu banku i o tome vodili evidenciju. U: Slovenec, 4. jul 1917, br. 150, 5, Primorske novice.

\footnotetext{
${ }^{75}$ Isto

${ }^{76}$ Svoljšak, Soča, sveta reka, 324.
} 
Dešavalo se da italijanske vlasti hapse ljude koji su išli da obrađuju njive. Ipak, seljaci su obrađivali svoju zemlju koliko su im dopuštale prilike, bez obzira na te prepreke. ${ }^{77}$

Italijanski okupator je obezbedio da "podređen narod" nije bio gladan i da nešto i dodatno zaradi. Istovremeno je vodio računa da slovenačko stanovništvo sistematski pretvori u Italijane. U Kobaridu italijanski okupator je prekrečio većinu kuća da bi obrisao sve slovenačke napise. Ulice i različite kancelarije dobile su italijanska imena. Imena ulica bila su Via Vitorio Emanuele, Via Čividale itd. Domaćini su mogli da čitaju samo italijanske novine. Okupator je na taj način želeo da izbriše svaki slovenački trag. Kobarid je polako menjao svoj slovenački izgled i poprimao sve znakove italijanske prisutnosti. Italijanski okupator je posvećivao pažnju i vaspitanju omladine. Narodnu školu su preimenovali u „Edukatorio“; slovenački učitelji nisu smeli više da predaju, zamenili su ih italijanski učitelji; nastava je održavana isključivo na italijanskom jeziku. Cilj je bio da se omladina vaspita u italijanskom duhu. Sva deca dobila su u školi besplatan ručak i užinu. U vreme slavlja (posete visokih italijanskih zvaničnika, različiti italijanski praznici) deca su nastupala u paradi, noseći italijanske kokarde, na kojima je bilo utisnuto Isusovo Srce, i držeći italijanske zastavice ${ }^{78}$ Cilj italijanskog okupatora bio je jasan - otuđiti i denacionalizovati okupirane slovenačke krajeve. Ispunjenje svog osnovnog cilja morao je u oktobru 1917. na kratko prekinuti, ali ga je ubrzo sistematski nastavio, pogotovo u periodu fašizma. ${ }^{79}$

Osnovni cilj italijanske politike i razlozi zbog kojih se opredelila za rat ogledaju se u takozvanim "oslobođenim pokrajinama“. Veneto i Trident za Italiju nisu predstavljali stranu već nacionalnu teritoriju, koja je u rukama neprijatelja i potrebno ju je vratiti italijanskom narodu. Italijanska vojska je zaposela slovenačku teritoriju ubeđena da „oslobađa neoslobođene kćerke i sinove“. Takva slika bila je predstavljena svakom italijanskom vojniku koji je odlazio u rat. Utoliko je veće bilo iznenađenje i razočarenje jer "oslobođena braća i sestre" nisu sa radošću primili svoje „spasitelje“. Ta činjenica, kao i nepoznavanje slovenačkog jezika i kulture, izazvali su kod italijanske strane paničnu sumnjičavost. Počelo je nasilje nad civilima. Streljanje civilnog stanovništva bila je česta mera prema stanovništvu okupirane teritorije, pogotovo u početnoj fazi okupacije. Najčešća mera vojske za nadziranje okupirane teritorije bila je internacija sumnjivih osoba. Takve

${ }^{77}$ Isto, 325-326.

${ }^{78}$ Slovenec, 15. novembar 1917, br. 5, Črtice o Kobaridu.

${ }^{79}$ Vili Prinčič, Lojze Ličen - spomini na prvo svetovno vojno, Na fronti: revija za vojaško zgodovino, novembar 2010, br. 6, Nova Gorica 2010, 53. 
mere koristila je i vrhovna komanda italijanske vojske. Hapšenja i internacije sveštenika i civila, pogotovu predstavnika lokalnih vlasti i učitelja, počeli su već 24 . maja 1915. i nastavili se u narednim nedeljama pod optužbom austrofilske orijentacije. Posle početnog nasilja i iseljavanja prilike na okupiranoj teritoriji postepeno su se smirivale, a italijanska strana se koncentrisala na organizaciju svakodnevnog života okupiranog područja. Snabdevanje životnim potrepštinama bilo je bolje nego na austrougarskoj strani. Čak su i porodice koje su imale svoje muške članove u austrougarskoj vojsci vremenom dobile skromnu novčanu pomoć italijanske države. Pozitivni postupci italijanske vlasti ipak ne dovode u pitanje suštinu politike Italije na okupiranom području - otuđiti stanovništvo od slovenačke pripadnosti, čime je Italija sasvim zaobišla odredbe haškog prava i okupacionu teritoriju 1915. godine, bez obzira na sve, tendenciozno pretvarala u italijansku teritoriju, iako je formalno pravno dobila tek posle Rapalskog ugovora.

Vladimir Prebilič, Dunja Dobaja

\section{THE INFLUENCE OF THE ISONZO FRONT ON SLOVENIAN LITTORIAL AND ITS POPULATION}

\section{Summary}

The article describes the Italian occupation of the Austrian (Slovenian) territory near the Isonzo (Soca) River in 1915 and its consequences. Italy had the perception that with this action, it liberates „unliberated brothers". Following this judgment, Italian side expected warm welcome with the inhabitants, but it never came. The cold reception of the Italian troops, created the suspicions, which later turned to a psychosis of fear, and later a kind of "spy psychosis". The inhabitants of this area were charged for the espionage and reconnaissance of the Italian front lines for the Austrian side. Such relations provoked violence against the civilians. The establishing of the Isonzo Front provoked the mass migrations of the local population. Period between 1915 and 1917 was marked with harsh living conditions of the population which remained in the area and creation of the camps on both sides from those which were refugees. Although marked as the war which did not directly was related to the civilians, in this area, its consequences have a dramatic effect against the civilian population, couple with violence and breaking of the international military and humanitarian regulations. 